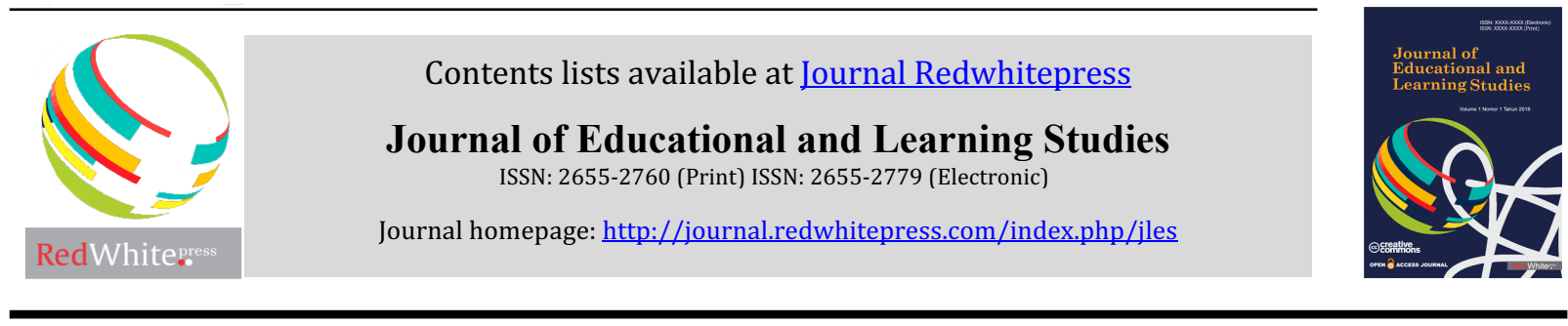

\title{
The Effectiveness of Intelligent Character Education- Group Format (ICE-GF) to Prevent Student Bullying Behavior
}

\author{
Diantifani Harlianda ${ }^{1}$, Prayitno $^{2}$, Mudjiran $^{3}$ \\ ${ }^{123}$ Guidance and Counseling Department, Universitas Negeri Padang, Padang, West Sumatra Indonesia
}

\begin{tabular}{|c|c|}
\hline Article Info & ABSTRACT \\
\hline Article history: & The phenomenon of bullying in Indonesia is very worrying for the \\
\hline Received Mar $12^{\text {th }}, 2020$ & $\begin{array}{l}\text { development of teenagers' life. This study used a quantitative approach with an } \\
\text { experimental method. The design used was a pre-experimental one group }\end{array}$ \\
\hline Revised Jul $20^{\text {th }}, 2020$ & pretest-posttest design. The data were collected from 33 students as the sample \\
\hline Accepted Aug $2^{\text {nd }}, 2020$ & $\begin{array}{l}\text { of this study taken by using a purposive sampling technique. The experimental } \\
\text { group was divided into } 3 \text { groups, namely group A, group B and group C. Each }\end{array}$ \\
\hline Keyword: & $\begin{array}{l}\text { group consisted of } 11 \text { members. The data were collected by using a } \\
\text { questionnaire students' BMB3 conditions about bullying }(55 \text { valid items }=\end{array}$ \\
\hline Intelligent Character Education & 0.889). Data were analyzed by using the Wilcoxon signed rank test with the \\
\hline Group Format (ICE-GF) & help of SPSS version 20.00 to measure the differences between two paired \\
\hline Bullying & $\begin{array}{l}\text { groups on ordinal data. The findings of the study showed that intelligent } \\
\text { character education-group format was effective for improving the conditions } \\
\text { about thinking, feeling, behaving, acting, and being responsible for the students } \\
\text { against bullying so it can prevent bullying behavior. }\end{array}$ \\
\hline
\end{tabular}

(C) 2020 The Authors. Published by Redwhitepress.

This is an open access article under the CC BY-NC-SA license

(https://creativecommons.org/licenses/by-nc-sa/4.0/

\section{Corresponding Author:}

Diantifani Harlianda, Universitas Negeri Padang

Email: diantifaniharlianda@gmail.com

\section{Introduction}

Bullying is deliberate aggressive treatment by certain individuals / groups to hurt physically and psychologically individuals who may feel powerless against the treatment. Bullying that can be done can be in the form of physical, verbal, relational bullying or bullying through cyberspace / internet called cyberbullying, which happens repeatedly by the bullying to the victim (Priyatna, 2010). Bullying also occurs in several forms of action, namely physical bullying, verbal bullying, and relational bullying (Coloroso, 2007). Bauman (2008) classify bullying behavior into 3 categories: Overt Bullying, Indirect Bullying, and Cyberbullying. Teenagers can do cyberbullying through social media (Bauman \& Pero, 2010).

Bullying is the part of a problem that can be done or experienced by anyone, for example teenagers who are in the process of undergoing education. Bullying that occurs in teenagers can be caused by a condition of disintegration between character and intelligence in individuals (Alizamar, 2015). Bullying has an impact on its victims which is feeling uncomfortable, intimidated, feeling inferior, difficult to concentrate on learning, easily anxious, tends to be private and closed, and reluctant to go to school (Magfirah \& Rachmawati, 2009). Bullying has an impact on mental health such as excessive anxiety, depression and suicidal thoughts (Hertz et al., 2013). Bullying can have an impact on the educational aspect, namely victims of bullying will become uncomfortable at school, cannot participate in the learning process actively because they are disturbed, and may even miss their school. Based on 6 education focuses they can give some impacts, such as; (1) religious spiritual strength has the effect of blaming God for what happened to him, (2) low self-control in controlling emotions, (3) a pessimistic personality, (4) inhibition of the development of intelligence such as difficulty 
finding solutions to problems that befall him, (5) in terms of noble character, they can behave defiantly due to the feeling of revenge that the victim has as a perpetrator, and (6) in terms of skills, it will be difficult to develop skills due to insecurity and depression (Prayitno, 2018).

Students can be avoided from a bullying behavior with the help of guidance and counseling teachers / counselors through the process of providing guidance and counseling services. One type of service in guidance and counseling services is group guidance services in groups of 8-15 students. BK teachers / counselors should provide guidance and counseling services in schools by giving the primary attention to all students, not only students with problems and providing guidance and counseling services to all students so that students can develop their potential optimally. This shows that guidance and counseling services are an important part of education which has the aim of helping all students develop all their potential to be able to develop optimally in achieving a successful future, with the development of daily life that is effective and avoiding from the life of the effective daily activities that are disturbed by an independent personal focus capable of self-control organized through various types of services and supporting activities in the learning process (Prayitno \& Amti (2013).

Intelligent Character Education (ICE) is an educational effort that harmoniously develops character and intelligence, which includes six educational focuses as stated earlier. Intelligent character education provides an opportunity for individuals to be able to understand, follow directions and utilize the facilities that are given by the Creator, while minimizing and if it is possible ICE makes zero negative aspects and activates the dynamics of self-development for participants towards harmony, compatible, and balance between personal and togetherness. Contents of learning activities Intelligent Character Education directly and dynamically leads to the living and practice of intelligent character values, including the noble values of Pancasila and 1945 Constitution in daily life both personally, family, community, nation and state (Prayitno et al., 2016).

Intelligent Character Education (ICE) can be generally used by all educators who have been trained as facilitators by seniors who have experience implementing Intelligent Character Education (ICE). However, the implementation of Intelligent Character Education- Group Format (ICE-GF) is more aligned if it is carried out by BK teachers / counselors because it has the same main operations as Group Guidance services (Prayitno et al., 2016). There are various cases of bullying that occur among teenagers. For example the case of bullying in the form of beatings carried out by colleagues, which caused the victim to die at M. Djamil Padang General Hospital (Hendri, 2019).

The Data on the Indonesian Child Protection Commission / Komisi Perlindungan Anak Indonesia (KPAI) from 2011-2019 revealed that 37,381 cases of violence were received. There were 2,473 reports of bullying that occurred in the educational environment and on social media and the trend will continue to increase (KPAI Team, 2020).

The effort that needs to be made by the teachers / counselors to provide assistance to students so that students can prevent bullying behavior is by implementing an Intelligent Character Education-Group Format (ICE-GF). Intelligent Character Education-Group Format (ICE-GF) is considered appropriate to be used in preventing student bullying behavior, with the character-intelligent group format education students can specifically know and understand that bullying is contrary to the values of intelligent character and has sufficient impact. Such bullying should be stopped, thus a study was carried out on the effectiveness of Intelligent Character Education-Group Format to prevent student bullying behavior.

\section{Method}

This study used a quantitative approach with an experimental method. The design used was a preexperimental one group pretest-posttest design. Experimental research is an activity that is deliberately used to manipulate and control independent variables to show directly its effect on the dependent variable (Yusuf, 2013). The population of this study was the students Grade X SMAN 15 Padang, totaling 287 students and there were perpetrators and victims of bullying. The sample in this study was selected by using a purposive sampling technique, amounting to 33 students, with the characteristics of the students who have a tendency to behave bullying, students who have done bullying, and students who have experienced bullying.

The instrument used in this study was by using a grand theory bullying from (Coloroso, 2007) and the BMB3 conditions (Thinking, Feeling, Behaving, Acting, Being responsible) from (Prayitno, 2015) with the indicators of how to think about bullying, feel about bullying, behave about bullying, act about bullying, and take responsibility about bullying. The questionnaire students' BMB3 conditions about bullying used alternative answers: strongly agree, agree, disagree, disagree, and strongly disagree. The validity of the instrument was analyzed by using a Product Moment analysis, so from 75 statement items there were 55 valid items and 20 invalid items. The reliability of this research instrument was Cronbach's Alpha value of 0.889 with a minimum value of Cronbach's Alpha instrument 0.80 . This showed that this research instrument was reliable with a very reliable level of reliability (Arikunto, 2010). The data were analyzed by using the descriptive statistical analysis 
and non-parameteric statistics using the Wilcoxon Signed Ranks Test with the help of SPSS 20.00. The Wilcoxon test is an alternative to the paired sample $t$ test, which is to measure the significance of the differences between the two groups, the conditions of which are not normally distributed data and ordinal or interval data scales (Siegel, 2008). The aim is to test the effectiveness of Intelligent Character EducationGroup Format (ICE-GF) to prevent bullying behavior.

\section{Results and Discussions}

Intelligent Character Education- Group Format (ICE-GF) was thought to be more effective in preventing bullying behavior. In order to prove this hypothesis, in detail, there is the following analysis.

Table. 1 The results of the Wilcoxon Signed Ranks Test analysis on the students' BMB3 conditions about bullying in the ICE-GF Group in the Pretest and Posttest.

\begin{tabular}{ll}
\hline & Posttest-Pretest \\
\hline $\mathrm{Z}$ & $-5.012^{\mathrm{b}}$ \\
\hline Asymp. Sig. (2-tailed) & .000
\end{tabular}

Through the Wilcoxon signed ranks test in the table above, the $\mathrm{Z}$ value is -5.012 and the Asymp sig value. (2-tailed) is 0.000 smaller than the alpha level $(0.05)$, which means that the data is significant, so the data can be accepted / trusted. Thus, the conclusion of the research hypothesis is that there is a significant difference on the level of the students' BMB3 conditions regarding bullying between before and after being given the Intelligent Character Education-Group Format (ICE-GF) treatment.

Table 2. The Differences in Pretest and Posttest Results (Wilcoxon Signed Ranks Test) of the Students' BMB3 Conditions on Bullying

\begin{tabular}{cccccc}
\multicolumn{7}{c}{ N } & Mean & Std.Deviation & Minimum & Maximum \\
& & & & & \\
\hline Pretest & 33 & 167.70 & 46.082 & 100 & 235 \\
\hline Posttest & 33 & 250.61 & 20.644 & 186 & 275 \\
\hline
\end{tabular}

The difference between the pretest and posttest results can be seen from the results of the mean, standard deviation (SD), minimum score and maximum score. In Table 2, it is known that the increase in mean, minimum and maximum scores, while the standard deviation (SD) has decreased in scores. This indicated that the distribution of data tends to be very close or close to data variations.

Thus, it can be concluded that the Intelligent Character Education- Group Format (ICE-GF) is effective in preventing the student bullying behavior. To see how the changes in the students' BMB3 condition scores about bullying to 33 students in the experimental group are detailed in the graph below, as follows.

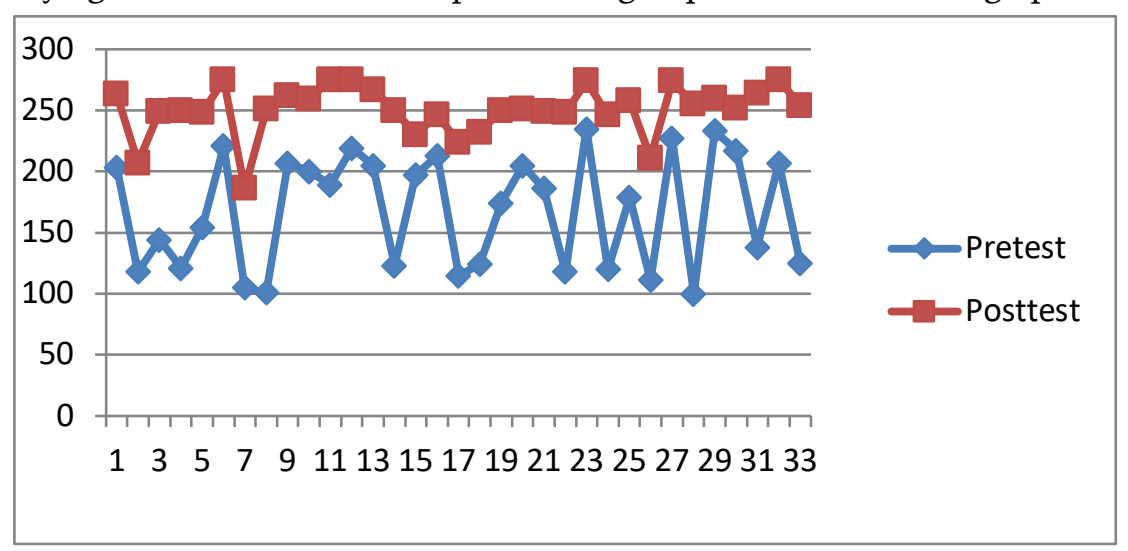

Graph 1. The Differences in Graph of the Students' BMB3 Conditions about Bullying Before (Pretest) and After (Posttest) Getting the Intelligent Character Education-Group Format (ICE-GF) Treatment 
Based on graph 1 above, it can be seen that there was an increase in the student's BMB3 condition score regarding bullying before and after receiving the Intelligent Character Education-Group Format (ICEGF) treatment. This showed that the Intelligent Character Education-Group Format (ICE-GF) can prevent student bullying behavior.

\section{The Research Results of the Students' BMB3 Conditions on Bullying}

Students who initially had a high BMB3 conditions about bullying were able to avoid bullying behavior. Moreover, after receiving the treatment, the students became more insightful about bullying in the form of bullying, the dangers of bullying and its effects. The results of hypothesis testing showed that "there is a significant difference in the level of the students' BMB3 conditions regarding bullying before and after the Intelligent Character Education-Group Format (ICE-GF)". Intelligent Character Education-Group Format (ICE-GF) can significantly increase the score changes in the students' BMB3 conditions regarding bullying.

The activity of the Intelligent Character Education-Group Format (ICE-GF) makes students become very enthusiastic and actively participate in activities so as to obtain new things that can be utilized in everyday life to develop effective everyday life by observing and practicing the values of the intelligent character to avoid disturbed daily effective life. Therefore, ICE-GF is appropriate and meaningful for students, which will provide new knowledge and experience to appreciate and practice intelligent character values for the students towards the students' BMB3 conditions about bullying in order to avoid bullying behavior (Prayitno et al., 2016).

\section{Conclusions}

Based on the research results that have been obtained, after carrying out non-parametric statistical analysis tests and hypothesis testing, it can be concluded that the Intelligent Character Education-Group Format (ICE-GF) method is effective in preventing student bullying behavior. There was a difference in students 'BMB3 condition level scores regarding bullying before and after participating in ICE-GF activities, where the mean score after posttest has increased on the students' BMB3 conditions about bullying significantly. The difference in the pretest-posttest scores prove the validity and reliability of the hypothesis that the researcher has provided in this study.

\section{References}

Alizamar. (2015). Pengembangan karakter cerdas mahasiswa melalui infusi dalam pembelajaran. Makalah disajikan dalam Seminar Internasional Konseling, Fakultas Ilmu Pendidikan UNP, Padang, 13-14 Maret

Arikunto, S. (2010). Prosedur penelitian suatu pendekatan praktik. Jakarta: Rhineka Cipta.

Bauman, S. (2008). The role of elementary school counselors in reducing school bullying. Elementary school journal, 108 (5), 362-375

Bauman, Sheri \& Pero, Heather. (2010). Bullying and cyberbullying among deaf students and their hearing peers: An exploratory study. Journal of deaf studies and deaf education, 16 (2), 236-253

Coloroso, B. (2007). Stop bullying: memutus rantai kekerasan anak dari prasekolah hingga SMU. Diterjemahkan oleh: Santi Indra Astuti. Jakarta: Serambi Ilmu Semesta

Hendri, Paul. (2019). Pengeroyokan santri berujung maut. Retrieved Agustus 20, 2019 from http ://www.metroandalas.co.id/berita-pengeroyokan-santri-berujung-maut-kpai-harap-pelaku-dihukumsetimpal.html.

Hertz, M. F., Donato, I., \& Wright, J. (2013). Bullying and suicide: A public health approach. Journal of Adolescent Health, 53 (5) 269-279

Magfirah, U \& Rachmawati, M. A. (2009). Hubungan antara iklim sekolah dengan kecenderungan perilaku bullying. Jurnal Psikohumanika, 2(1), 2-12

Prayitno. (2015). Konseling integritas (pola konseling Indonesia). Padang: Paramitra Publishing

Prayitno. (2018). Landasan keilmuan dan keprofesionalan bimbingan dan konseling. Padang: UNP Press.

Prayitno dan Amti, E. (2013). Dasar-dasar bimbingan dan konseling. Jakarta: Rineka Cipta.

Prayitno, Mudjiran, Khaidir, A., Ifdil \& Rangka, B. Itsar. (2016). Pendidikan Karakter-Cerdas: format kelompok (PKC-KO) dan format klasikal (PKC-KA). Padang: UNP Press

Priyatna, Andri. (2010). Lets end Bullying: Memahami, mencegah dan mengatasi bullying. Jakarta: Kompas Gramedia

Siegel, S (2008). Statistika non-parametrik untuk ilmu-ilmu Sosial. Jakarta: Gramedia. 
Tim KPAI. (2020). Sejumlah kasus bullying sudah warnai catatan masalah anak di awal 2020 begini kata komisioner kpai. Retrieved Maret 22, 2020 from http://www.kpai.go.id/berita/sejumlah-kasus-bullying-sudahwarnai-catatan-masalah-anak-di-awal-2020-begini-kata-komisioner-kpai/ 